\title{
Impact of Business Plans for the Development of MSMEs
}

\author{
Irwan Sugiarto \\ Law College of Bandung, Indonesia \\ irwansugiarto8@gmail.com
}

\begin{abstract}
This study aims to determine the impact of business planning for the development of MSMEs. The research method uses is a qualitative method with a descriptive and explorative descriptive approach. From the results of the research conducted, the results show that proper business planning and the application of a good marketing strategy have a positive impact on the sustainability of MSME activities. In addition, the quality of production that has a competitive advantage is also one of the driving factors. For the development of MSMEs, there are several obstacles faced, especially related to capital and guidance from the local government. With the development of MSMEs, it is expected to improve people's welfare, including helping the government in reducing unemployment.
\end{abstract}

Keywords : MSMEs; business planning; competitive advantage

\section{Introduction}

In developing the national economy, the Indonesian government issued policies relating to MSMEs as a top priority to reduce poverty and increase community income [1]. In addition, MSMEs are superior products owned by each region based on a populist economy that elevates local wisdom to be able to compete with other similar products [2], [3].

To have the competitiveness of business people must plan the business that will be carried out by making the right business plan. Business planning is made by business people so that the decisions taken are strategies related to the business they are running in order to grow and develop in accordance with the vision, mission, and expected strategic plans [4], [5], [6], [7]. With the right business planning, it is expected that business people can integrate with suitable and appropriate activities to be implemented effectively [8], [9].

However, there are still many business people, especially MSME players who can carry out their activities not planned so that their development is difficult to predict. In addition, without planning, the business actor cannot estimate the capital and target market that he wants to target. From the description above, the authors are interested in examining it more deeply related to the impact of the business plan for the development of MSME activities.

\subsection{Business Planning}

\section{Review of Literature}

In an uncertain global economy, business management and strategic planning play an important role, especially for the MSME sector [10]. According to Johnson [11] and David [12] the business strategy planning process includes strategic analysis, business strategy formulation, strategy implementation, and feedback, evaluation, and ex-post which are all related to long-term business goals. One of the strategic plans of the MSME business plan is related to financing for business development [13]. In addition, MSMEs have a very important role to play in creating jobs and supporting national economic growth [14].

This is in line with the opinion expressed by Zich [15] that management must be able to implement a strategy from a predetermined business plan in order to have high competitiveness with similar products from other companies. Zich's opinion is supported by the opinions expressed by Skokan [16], Hitt [17], Glaister et al. [18] that with the existence of a business plan, MSME activities can develop innovations, implement appropriate business strategies, as 
well as the company's competitiveness in the long term. The results of empirical research conducted by Bracker et al. [19], Lyles et al. [20], and Gibson \& Cassar [21] it can be concluded that many business organizations failing to run their wheels are caused by not having a clear business plan. and do not consider competitive advantages over the products they produce.

\subsection{Competitive Advantage}

MSMEs are the lifeblood and support for economic growth for the Indonesian people. this can be seen during the economic crisis of 1998, MSMEs can become a pillar of the Indonesian economy and can survive in world economic uncertainty [22], [23], [24]. MSMEs and small industries can survive in the midst of the economic crisis because they have the advantage of the quality they produce [25]. This is supported by the opinion expressed by Kim $\&$ Peterson [26] that the superiority of a product can be a competitive competitiveness in the eyes of consumers and it is possible that business activities can survive better in times of crisis.

From the results of empirical research conducted by Moertini [27], Zhang et al. [28], and [29] it is known that competitive advantage can be obtained by business people if they can provide services and supply of products needed by consumers and have qualities that are not owned by products of other similar companies.

\section{Research Method}

The research was conducted from January to March 2019. The method used was a qualitative method with a descriptive explorative approach. The object of the research was the Motorcycle Jacket business with the trademark ASP Jacket which is located on Jalan Cihampelas, Bandung. The type of data collected was primary data obtained through in-depth interviews with information sources (informants). In conducting surveys, researcher used a personal approach (unstructured questionnaire) to obtain information related to the bag industry business. Data analysis techniques in this study used a descriptive qualitative interactive model in the form of data collection, data reduction, display data, and conclusions / interpretative verification.

\section{Results and Discussion}

Research conducted on MSMEs that produce community jackets that discuss the basic Cordura. The strength of the cordura material is that it is not translucent. The jacket that we will market is targeted at motorbike riders, motorcycle clubs and police agencies, transportation and others. Some of the products they produce can be seen in the following picture:
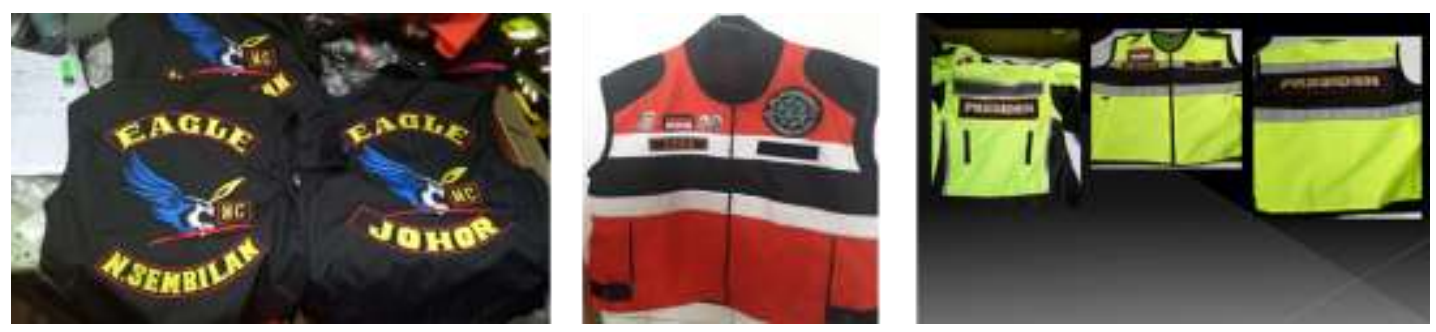

Figure 1. Production Results of ASP Jacket

Figure 1 above can be explained that community jackets in the millennial era are not only used by government and police agencies, but many motorcycle communities also use jackets 
produced by ASP Jacket. From the results of interviews with the owner and manager of the community jacket industry, information was obtained that the intended target market was from middle to upper class economic circles. Furthermore, it was explained, in its business development, the MSMEs utilizes information technology, especially the internet, to market its products (online). This is done because online marketing is more optimal than conventional sales.

The endurance of the business that has been cultivated since 2014 is inseparable from the quality of its products. Some motorcycle communities that use ASP production jackets can be seen in the following picture:
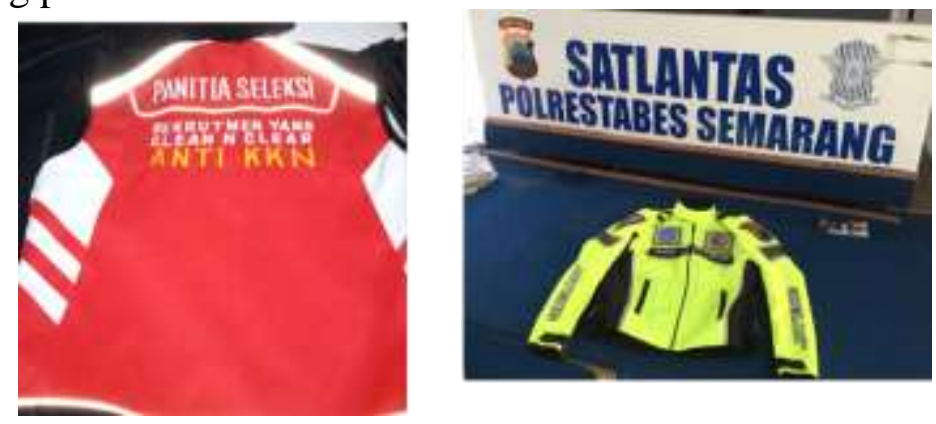

Figure 2. ASP User Production Jacket Community

The large number of communities that utilize ASP production jackets is inseparable from business plans that are arranged regularly and implement marketing strategies that are appropriate, effective, and useful for its users. This is in accordance with the vision of ASP production, namely "To be the best and highest quality Jacket Company and always meet consumer expectations". This is certainly in line with the opinion expressed by Kumar \& Petersen [25] and Kim \& Peterson [26] that production products that have the best quality and have competitive advantages and are supported by proper business planning will be the main attraction for consumers. Thus the results of the research conducted by Bracker et al. [19], Lyles et al. [20], and Gibson \& Cassar [21] that good business planning has a positive impact on the development of business organizations in the future in accordance with ASP Production, especially the carefulness in seeing the market potential of community jackets that are increasingly promising.

However, the obstacles faced by ASP Production in fulfilling the desires and needs of consumers collide with capital issues and the limited skills possessed by their employees. The role of the regional government, especially the Bandung city government, must be more intensive in providing guidance for MSME players considering the city of Bandung as a Culinary and tourism city in the province of West Java.

\section{Conclusion}

From the description above, it can be seen that the right business plan and good alignment strategy have a positive impact on the development of MSMEs. The large number of MSMEs that fail in carrying out their business is caused by several factors including limited capital, skills, and the absence of a clear and precise business plan. Some of the obstacles experienced by many MSMEs are mainly related to the limited capital and mastery of information technology. 


\section{References}

[1] Ana Yuliana Jasuni, Muhammad Firdaus, and Bunasor Sanim, "Mocro Financing Optimalization Strategy for MSMEs Development (Case Study at Kabupaten Bogor Indonesia)," Indonesian Journal of Business and Entrepreneurship, vol. 4, no. 2, pp. 161-169, 2018.

[2] Ade Octavia, Zulfanetti, and Erida, "Meningkatkan daya saing daerah melalui peningkatan kinerja bisnis usaha mikro, kecil dan menengah di Provinsi Jambi," Jurnal Perspektif Pembiayaan dan Pembangunan Daerah, vol. 4, no. 3, pp. 155-166, 2017.

[3] Adijat Morenikeji Safiriyu and Bibiana Oluchukwu Njogo, "Impact of small and medium enterprises in the generation of employment in lagos state," Kuwait Chapter of Arabian Journal of Business and Management Review, vol. 1, no. 11, pp. 107-141, 2012.

[4] Oleksiy Osiyevskyy, Lesley Hayes, Norris Krueger, and Cameron Maranville Madill, "Planning to Grow? Exploring the Effect of Business Planning on the Growth of Small and Medium Enterprises (SMEs)," Entrepreneurial Practice Review, vol. 2, no. 4, pp. 36-56, 2013.

[5] Benson Honig, "Entrepreneurship education: Toward a model of contingency-based business planning," Academy of Management Learning \& Education, vol. 3, no. 3, pp. 258-273, 2004.

[6] Mesut Savrul, Ahmet Incekar, and Sefer Sener, "The Poᄀtential of E-Commerce for SMEs in a Glo $\neg$ balizing Business Environment," Procedia-Social and Behavioral Sciences, vol. 150, pp. 3545, 2014.

[7] Sebastian Kot, "Sustainable Supply Chain Management in Small and Medium Enterprises," Journal of Sustainability, vol. 10, no. 4, pp. 1-19, 2018.

[8] Richard B. Robinson and John A. Pearce, "Research Thrusts in Small Firm Strategic Planning," Academy of Management Review, vol. 9, no. 1, pp. 128-137, 1984.

[9] Nathan R. Furr and Paul Ahlstrom, Nail It then Scale It: The Entrepreneur's Guide to Creating and Managing Breakthrough Innovation, 1st ed.: NISI Press, 2011.

[10] Skokan Karel, Pawliczek Adam, and Piszczur Radomir, "Strategic Planning and Business Performance of Micro, Small and Medium-Sized Enterprises," Journal of Competitiveness, vol. 5, no. 4, pp. 57-72, 2013.

[11] Gerry Johnson, Kevan Scholes, and Richard Whittington, Exploring Corporate Strategy, 8th ed.: Harlow: Pearson Education Ltd, 2008.

[12] Fred R. David, Strategic Management. Concepts and Cases, 13th ed.: Prentice Hall, 2013.

[13] Margarita Ekadjaja, Halim Putra Siswanto, and Agus Zainul Arifin, "Factors Determining Bank Loan Approval as Source of Financing for Micro, Small, and Medium Enterprises (MSMEs) in Jakarta," Journal Muara Ilmu Ekonomi dan Bisnis, vol. 2, no. 1, pp. 226-233, 2018.

[14] Maria Giaoutzi, Peter Nijkamp, and David J. Storey, Small and Medium Size Enterprises and Regional Development, 1st ed. London, Inggris: Routledge Library Editions, Oxford, 2016.

[15] Robert Zich, "Koncepce úspěchuschopnosti a její pojetí strategie," E+M Economics and Management, vol. 13, no. 1, pp. 60-73, 2010.

[16] Karel Skokan, "Inovační paradox a regionální inovační strategie," Journal of Competitiveness, vol. 2, no. 2, pp. 30-46, 2010.

[17] Michael A. Hitt, R. Duane Ireland, and Robert E. Hoskisson, Strategic Management: Competitiveness and Globalization (Concepts and Cases), 11th ed.: Cengage Learning, 2014.

[18] Keith W. Glaister, Omer Dincer, Ekrem Tatoglu, Mehmet Demirbag, and Selim Zaim, "A causal analysis of formal strategic planning and firm performance: Evidence from an emerging country," Management Decision, vol. 46, no. 3, pp. 365-391, 2008. 
[19] Jeffrey S. Bracker, W. Keats Barbara, and John N. Pearson, "Planning and financial performance among small firms in a growth industry," Strategic Management Journal, vol. 9, no. 6, pp. 591603, 1988.

[20] L.S. Baird, Marjorie A. Lyles, J. Burdeane Orries, and D.F. Kuratko, "Formalized Planning in small business: increasing strategic choices," Journal of Small Business Management, vol. 31, no. 2, pp. 38-50, 1993.

[21] Brian Gibson and Gavin Cassar, "Planning behaviour variables in small firms," Journal of Small Business Management, vol. 40, no. 3, pp. 171-186, 2002.

[22] Rosli Mohamad and Noor Azizi Ismail, "Electronic Commerce Adoption in SME: the Trend of Prior Studies," Journal of Internet Banking and Commerce, vol. 14, no. 2, pp. 1-16, 2009.

[23] Ramakrishnan Ramanathan, Usha Ramanathan, and Hsieh Ling Hsiao, "The Impact of ECommerce on Thai ᄀwanese SMEs: Marketing and Operations Efeect," International Journal of Production Economics, vol. 140, no. 2, pp. 934-943, 2012.

[24] Necmi Karagozoglu and Martin Lindell, "Electronic commerce strategy, operations, and performance in small and medium-sized enterprises," Journal of Small Business and Entrepreneurship Development, vol. 11, no. 3, pp. 290-301, 2004.

[25] Sameer Kumar and Palo Petersen,". Impact of E-Com $\neg$ merce in Lowering Operational Cost and Raising Customer Satisfaction," Journal of Manufacturing Technology Management, vol. 17, no. 3, pp. 283-302, 2006.

[26] Yeolib Kim and Robert A. Peterson, "A Meta-Analysis of Online Trust Relationship in ECommerce," Journal of Interactive Marketing, vol. 38, pp. 44-54, 2017.

[27] Veronica S. Moertini, "Small Medium Enterprises: On Utilizing Business-to-Business ECom?merce to Go Global," Procedia Economics and Finance, vol. 4, pp. 13-22, 2012.

[28] Danlei Zhang, Pengyu Zhu, and Yanmei Ye, "The Effects of E-Commerce on the Demand for Commercial Real Estate," Cities, vol. 51, pp. 106-120, 2015.

[29] Salah Kabanda and Irwin Brown, "A Structuration Analysis of Small and Medium Enterprise (SME) Adoption of E-Commerce: the Case of Tanzania," Telematics and Informatics, vol. 34, no. 4, pp. 118-132, 2017. 